\title{
Molecular detection and hematological changes in dogs naturally infected by Babesia vogeli in metropolitan region of Rio de Janeiro
}

\author{
Detecção molecular e alterações hematológicas de amostras \\ de cães naturalmente infectados por Babesia vogeli na região \\ metropolitana do Rio de Janeiro
}

Renata Quintela Assad* (D), Eloy da Silva Seabra Junior ${ }^{2}$ (D), Monique Moraes Lambert ${ }^{3}$ (D), Carmen Beatriz Seti Corrêa ${ }^{4}$ (D), Tatiana Didonet Lemos $^{5}$ (D) , Helena Keiko Toma ${ }^{6}$, (D), Fabio Barbour Scott ${ }^{7}$ (D), Nádia Regina Pereira Almosny ${ }^{8}$ (1)

VVeterinarian, MSc. Departamento de Patologia e Clínica Veterinária - DPCV, Universidade Federal Fluminense - UFF, Niterói, RJ, Brasil Biological Sciences, Graduate student. Departamento de Patologia e Clínica Veterinária, Universidade Federal Fluminense UFF, Niterói, RJ, Brasil

${ }^{3}$ Veterinarian, Dr. Laboratório de Quimioterapia Experimental em Parasitologia Veterinária - LQEPV, Departamento de Parasitologia Animal - DPA, Universidade Federal Rural do Rio de Janeiro - UFRRJ, Seropédica, RJ, Brasil

${ }^{4}$ Veterinarian, Resident in Clinical Pathology. Hospital Veterinário, Universidade Federal Rural do Rio de Janeiro - UFRRJ, Seropédica, RJ, Brasil

${ }^{5}$ Veterinarian, Dr. Centro de Ciências da Saúde, Centro Universitário Serra dos Órgãos - UNIFESO, Teresópolis, RJ, Brasil ${ }^{6}$ Biological Sciences, Dr. Laboratório de Diagnóstico Molecular e Hematologia, Faculdade de Farmácia, Universidade Federal do Rio de Janeiro - UFRJ, Rio de Janeiro, RJ, Brasil

`Veterinarian, Dr., PhD. Laboratório de Quimioterapia Experimental em Parasitologia Veterinária - LQEPV, Departamento de Parasitologia Animal - DPA, Universidade Federal do Rio de Janeiro - UFRJ, Seropédica, RJ, Brasil

\&Veterinarian, Dr. Departamento de Patologia e Clínica Veterinária - DPCV, Universidade Federal Fluminense - UFF, Niterói, RJ, Brasil

\begin{abstract}
Canine babesiosis, one of the most prevalent tick-borne diseases worldwide, is an endemic disease in Brazil that has been detected in several locations. Anemia and thrombocytopenia are the most common hematologic changes in dogs with babesiosis. The aim of this study was to assess the prevalence of piroplasms, and hematological changes found in dogs in a metropolitan region of Rio de Janeiro served by the Small Animals Veterinary Hospital of the Federal Rural University of Rio de Janeiro. The 18S rRNA gene was amplified by polymerase chain reaction (PCR) and sequence-based genetic characterization was performed. Of the total 250 blood samples that were randomly analyzed, nine (3.6\%) were positive for Babesia spp. Samples identified as positive for piroplasms by PCR were sequenced and Babesia vogeli was detected. The predominant hematological changes in piroplasm-positive dogs included anemia and thrombocytopenia, which were observed in six (66.7\%) and eight (89\%) dogs, respectively. The findings indicate that $B$. vogeli was the predominant piroplasm in most of the affected dogs in the studied metropolitan region. Piroplasm can cause changes, including anemia and thrombocytopenia, in affected animals.
\end{abstract}

Keywords: piroplasmosis, ticks, PCR, protozoon, molecular analysis.

\section{Resumo}

A babesiose canina é, no mundo inteiro, uma das mais importantes doenças transmitidas por carrapatos. É uma doença endêmica no Brasil e sua presença tem sido detectada em várias localidades. As alterações hematológicas mais comumenteencontradas em cães com babesiose são anemia etrombocitopenia. O objetivo desse trabalho foi avaliar a prevalência de piroplasmas e as alterações hematológicas encontradas em cães, da região metropolitana do Rio de Janeiro, que foram atendidos no setor de Pequenos Animais do Hospital Veterinário da Universidade Federal Rural do Rio de Janeiro (UFRRJ) através da amplificação do gene18SrRNA pela Reação em Cadeia de Polimerase (PCR) e caracterização genética através do sequenciamento. Foram utilizadas, aleatoriamente, 250 amostras de sangue de cães. Do total de amostras, nove (3,6\%) foram positivas para Babesia spp. pela PCR para piroplasmas. As amostras positivas foram sequenciadas e identificadas como Babesia vogeli. As alterações hematológicas predominantes nos animais positvos na PCR foram anemia em seis (66,7\%) e trombocitopenia em oito (89\%) cães. Conclui-se que Babesia vogeliéo piroplasma quemais acomete cães naquela região, podendo causar alterações como anemia e trombocitopenia nos animais acometidos.

Palavras-chave: piroplasmoses, carrapatos, PCR, protozoário, análise molecular.
How to cite: Assad, R. Q., Seabra Junior, E. S. Lambert, M. M., Corrêa, C. B. S., Lemos, T. D., Toma, H. K., Scott, F. B., \& Almosny, N. R.P(2O20). Molecular detection and hematological changes in dogs naturally infected by Babesia vogeli in metropolitan region of Rio de Janeiro. Brazilian Journal of Veterinary Medicine, 42, eO32120. https://doi.org/10.29374/2527-2179.bjvm032120

Financial support: This study was financed in part by the Coordenação de Aperfeiçoamento de Pessoal de Nível Superior - Brasil (CAPES) Finance Code 001.

Conflict of interests: No conflict of interests declared concerning the publication of this article.

Received: February 02, 2020

Accepted: April 04, 2020

The study was carried out at Pathology and Clinical Veterinary Department, Universidade Federal Fluminense, Niterói, RJ, Brasil.

\section{*Correspondence}

Renata Quintela Assad

Departamento de Patologia e Clínica Veterinária, Faculdade de Veterinária, Universidade Federal Fluminense - UFF Rua Vital Brasil Filho, 64 - Santa Rosa, CEP 24220-000, Niterói (RJ), Brasil E-mail: renataqassad@yahoo.com.br

Copyright Assad et al. This is an Open Access article distributed under the terms of the Creative Commons Attribution Non-Commercial License which permits unrestricted non-commercial use, distribution, and reproduction in any medium provided the original work is properly cited. 


\section{Introduction}

Babesiosis is caused by Babesia sp., an intra-erythrocytic protozoan transmitted by ticks (Irwin, 2009). Babsesia sp. is considered the most prevalent mammalian hemoparasite and has a wide worldwide distribution (Pantchev et al., 2015).

The genotypic classification of canine piroplasms has identified multiple Babesia species that infect dogs (Beck et al., 2009). Uilenberg (2006) suggested that the three subspecies of Babesia canis should be separate species and proposed that the group should be called Babesia canis sensu lato; the subspecies B. canis, B. rossi, and B. vogeli are different species within this group (Uilenberg, 2006). The different species of Babesia canis sensu lato vary markedly in terms of clinical signs, geographical distribution, and vector specificity (Cacciò et al., 2002). A species of Babesia, isolated from sick dogs in North Carolina (Birkenheuer et al., 2004), was subsequently designated as Babesia sp. (coco) (Lehtinen et al., 2008). Another, as yet unnamed species of Babesia, was found in Great Britain (Birkenheuer, 2012). In 2009, B. caballi was detected in infected dogs in Croatia (Beck et al., 2009). Rangelia vitalii, a piroplasm that infects dogs, has been detected in South America, particularly in Brazil (Loretti \& Barros 2005, Lemos et al., 2012), Argentina (Eiras et al., 2014), and Uruguay (Soares et al., 2015). R. vitalii is morphologically identical to the great Babesias, and species differentiation has been achieved using molecular analyses by polymerase chain reaction (PCR) and sequencing (Lemos et al., 2012).

Piroplasms that are smaller in size include B. gibsoni (Zahler et al., 2000b); B. conradae found in California (Kjemtrup \& Conrad, 2006; Kjemtrup et al., 2006); B. microti-like, also known as Theileira annae (Zahler et al., 2000a; García, 2006; Miró et al., 2015) or "Isolated from the Spanish dog" (Yeagley et al., 2009). Other described species include the Theileria spp. detected in South Africa (Matjila et al., 2008), T. annulata found in Spain, and T. equi (known as B. equi) isolated from infected dogs in Spain and Croatia (Criado-Fornelio et al., 2003; Birkenheuer et al., 2004; Beck et al., 2009).

In Brazil, babesiosis disease is of great veterinary importance, being endemic throughout the country, and has been increasingly reported in different places (Bastos et al., 2004). Molecular studies have characterized B. vogeli (Passos et al., 2005; Sá et al., 2006), B. gibsoni (Trapp et al., 2006), and $R$. vitalii as the agents responsible for canine piroplasmosis in Brazil (Silva et al., 2011; Soares et al., 2011; Lemos et al., 2012).

The severity of the infection varies and is generally associated with host age, immunity, co-infection with other pathogens, and/or genetic factors. The most common symptoms in the acute phase are fever, anemia, hemoglobinuria, jaundice, lethargy, malaise, and anorexia. The chronic phase is generally asymptomatic (Schnittger et al., 2012).

In general, Babesia sp. causes hemolytic anemia, which is multifactorial and is the predominant clinical manifestation leading to the immune response that can have a devastating effect on the infected animal (Ayoob et al., 2010). The acute phase can be lethal in puppies. Hemolytic anemia and a systemic inflammatory response can lead to multiple organ dysfunction syndrome (Taboada \& Lobetti, 2006).

Thrombocytopenia may be the only hematological alteration found and is frequently reported in dogs infected with Babesia sp. Thrombocytopenia can be related to immunity, splenic sequestration, or platelet consumption due to hemolytic changes or vascular injuries. Immunemediated thrombocytopenia has been demonstrated in experimental studies on infections with B. gibsoni in dogs (Wilkerson et al., 2001). However, abnormal coagulation parameters have not been frequently reported in dogs with babesiosis (Taboada \& Lobetti, 2006). According to Lobetti (2003), anemia and thrombocytopenia are the most frequent changes encountered in cases of babesiosis.

The aim of this study was to determine the prevalence of piroplasms in blood samples from dogs in the metropolitan region of Rio de Janeiro served by the Veterinary Hospital of Small Animals of the Federal Rural University of Rio de Janeiro (UFRRJ). The analyses involved PCR and sequencing, as well as the assessment of hematological changes caused by the protozoa. 


\section{Material and methods}

This study was approved by the ethics committee of Universidade Federal Fluminense under protocol number 582. Whole blood samples $(n=250)$ were collected from dogs in the metropolitan region of Rio de Janeiro that were treated at the Veterinary Hospital of the Federal Rural University of Rio de Janeiro, in the municipality of Seropédica, in Baixada Fluminense. The samples were collected from the jugular or cephalic vein, and individually place in a tube containing 10\% ethylenediaminetetraacetic acid (EDTA). The animals were randomly selected with no preference regarding sex, race, or age during March to June 2015.

The whole blood samples were used for the hemogram testing using an automated device (pocH 10Oiv; Sysmex). For hematozoa investigation, blood smears were prpeared and stained with Panótico Rápido ${ }^{\circledR}$ dye. The remaining blood was separated for PCR.

DNA was extracted from $300 \mu \mathrm{L}$ of each whole blood sample using the Illustra blood genomicPrep Kit (GE Healthcare) in accordance with the manufacturer's instructions. Extracted DNA was stored at $-20^{\circ} \mathrm{C}$ until use.

To detect specific piroplasmid DNA, PIRO A (5'-AAT ACC CAA TCC TGA CAC AGG G-3') and PIRO B (5'-TTA AAT ACG AAT GCC CCC AAC-3') primers were used. The primers amplified an 18S rRNA gene fragment of approximately $400 \mathrm{bp}$. The final reagent concentrations were $200 \mu \mathrm{M}$ of each dNTP, 200 nM of each primer, 1,625 mM MgCl , 1,25 U GoTaq ${ }^{\circledR}$ Flexi DNA polymerase (Promega), and $5 \mu \mathrm{L}$ of DNA sample in the final reaction volume of $25 \mu \mathrm{L}$, with the buffer provided by the manufacturer at the proper concentration. The reaction program was performed as follows: $94^{\circ} \mathrm{C}$ for $5 \mathrm{~min}$, followed by 30 cycles at $94^{\circ} \mathrm{C}$ for $1 \mathrm{~min}, 5^{\circ} \mathrm{C}$ for $1 \mathrm{~min}$, and $72^{\circ} \mathrm{C}$ for $1 \mathrm{~min}$. A final extension step was performed at $72^{\circ} \mathrm{C}$ for $5 \mathrm{~min}$ (Carret et al., 1999).

The PCR products were resolved by $1 \%$ agarose gel electrophoresis and stained with Gel Red ${ }^{\circledR}$ (Biotium) to assess the size of the DNA fragments produced. In all amplifications, samples known to be positive for $B$. vogeli were included as a positive control.

All positive samples were purified with the Illustra GFX PCR DNA Kit and Gel Band Purification Kit (GE Healthcare Life Sciences), following the manufacturer's instructions. The purified DNA was sequenced using an ABI Prism 3130 automatic sequencer (Thermo Fisher Scientific) and the Program for Technological Development of Health Products/ Fundação Oswaldo Cruz (PDTIS/FIOCRUZ) (RPTO1A) sequencing platform as described by Otto et al. (2008).

The sequences were aligned using the Clustal W version 2.1 program (Larkin et al., 2007) and alignment gaps were removed. A phylogenetic analysis was performed using the Phylogeny Inference Package (PHYLIP) as previously described (Felsenstein, 2005) using na analysis of maximum parsimony with a bootstrap number of 1000. A consensus tree was generated using the Seqboot, Dnapars, and Consense programs. Graphic processing of the tree was performed using Mega version 6.06. The sequences used in the comparison were B. canis rossi (HM585429), B. canis canis (AY072926), Babesia sp. isolate Okinawa dog-76 (AYO77719), and B. canis vogeli (AY072925). These were chosen because they are grouped in the same clade as B. vogeli in the proposed phylogeny of Lack et al. (2012). In addition, B. gibsoni (AY102164), Babesia sp. coco (AY618928), and R. vitalii (KT319117) were included for comparison because they are other species of piroplasms. The sequence of Plasmodium falciparum (AB100091) was chosen as the outgroup, as it is in a different clade from the clade of the evaluated piroplasm species (Lack et al., 2012). The sequences of that study were deposited in GenBank with the following accession codes: KU662363, KU662364, KU662365, KU662366, KU662367, KU662368, KU662369, KU662370 and KU662371.

\section{Results}

The intra-erythrocyte piroplasmid was detected by optical microscopy in five samples, corresponding to $2 \%$ of the total blood samples. Of the 250 samples, the $18 \mathrm{~S}$ rRNA gene for Babesia spp. Was amplified in 3.6\% (9/250), demonstrating that the sensitivity of the molecular technique was greater. Five (2\%) positive blood smear samples were also positive when PCR was performed. Sequencing identified all the samples as B. vogeli.

The sequences of the positive samples were $99 \%$ to $100 \%$ identical to B. canis vogeli (isolated from Belém [KT333456], Europa [AYO72925] and Okinawa [AYO77719]). In the phylogenetic tree, all sequences grouped internally to the $B$. canis vogeli clade, confirming the specific identity of B. vogeli (Figure 1). 


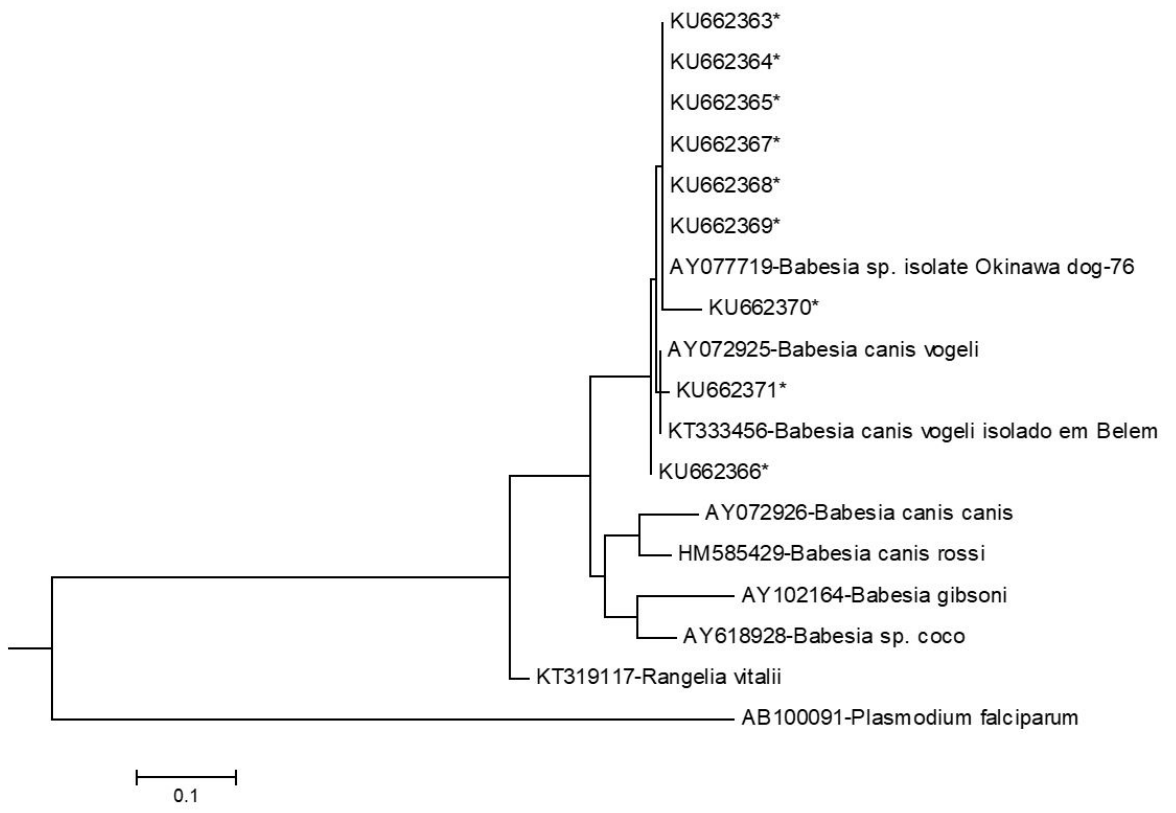

Figure 1. Phylogeny dendogram assessed in the molecular detection study of dogs naturally infected by Babesia vogeli in the metropolitan region of Rio de Janeiro. The sequences obtained by Genbank are preceded by their access numbers. The sequences marked with $\left(^{*}\right)$ are samples obtained in this study, which were positive for B. vogeli by PCR and sequencing. These sequences were identified with their GenBank accession numbers.

Hematological examinations revealed anemia in 66.7\% (6/9) of the dogs positive for B. vogeli. Associated with anemia, anisocytosis and polychromasia were observed in 67\% (6/9) of the dogs the were PCR-positive for piroplasms. Leukocytosis was found in one (11.1\%) of the nine positive dogs, and 55.6\% (5/9) presented with leukopenia. Only 11.1\% (1/9) presented monocytosis and 22\% (2/9) presented eosinophilia. Lymphopenia was evident in 78\% (7/9) of the samples. Thrombocytopenia was present in 89\% (8/9) of the positive animals.

\section{Discussion}

Soares et al. (2006) reported a $2 \%$ positivity rate for Babesia sp. in blood smears from domiciled dogs in Juiz de Fora, consistent with that found in the present study. O'Dwyer et al. (2001) reported a 5.2\% positivity rate in rural areas of Paraíba do Sul River Valley, in the state of Rio de Janeiro. Miranda et al. (2008) obtained a positivity rate of $1.47 \%$ in dogs from Campos dos Goytacazes in the same state. Araújo et al. (2015) found only two positive samples (0.5\%) in rural Pernambuco. The lower sensitivity of optical microscopy used by these authors as well as in the presente study was evidenced by the low frequency of parasitic forms of piroplasm detected in blood smears, which can be explained by the fact that parasites are rarely found in the peripheral blood of animals with subclinical infection (Weiss \& Wardrop, 2010). However, in a retrospective study in a metropolitan region in Salvador, Ungar de Sá et al. (2007) reported that 33.95\% $(2,459 / 7,243)$ of dogs had inclusions compatible with Babesia spp. in red blood cells using the blood smear technique. The higher rate of detection was likely because they used samples from animals suspected of babesiosis.

Lemos et al. (2012) reported a 3.9\% rate of positivity using optical microscopy and 6.8\% using PCR. This difference is consistent with the fact that parasitic forms are generally visualized in blood smears only during the acute phase. Therefore, when the parasite is not found in a blood smear, the possibility of infection cannot be exclused (Passos et al., 2005).

Sá et al. (2006) provided the first description of the presence of $B$. vogeli in Rio de Janeiro using the molecular methods of PCR and restriction fragment length polymorphism. The same approach was used in the present study, where 3.6\% of positive samples were found for the same species. Molecular techniques are useful for the identification of protozoa that infect dogs (Criado-Fornelio et al., 2003). 
The development of anemia in piroplasmosis is multifactorial and results from both intra and extravascular causes (Ayoob et al., 2010). Anemia was observed in 66.7\% of the piroplasmpositive animals in this study.

In Poland, anisocytosis and polychromasia rates of 60.5\% (150/248) and 23.8\% (59/248), respectively, were reported (Zynger et al., 2007). Compared with the current study, such changes were found concomitantly in $67 \%$ of animals that were positive for B. vogeli. Anisocytosis and polychromasia are changes that can be found in cases of anemia (Thrall, 2007).

In the present study, leukocytosis was observed in only one (11.1\%) of the nine positive dogs, while 55.6\% (5/9) presented with leukopenia; this may represent the initial stage of the disease, followed by neutrophilic leukocytosis (Abdullahi et al.,1990). Furlanello et al. (2005) found leukopenia in 69\% of animals positive for Babesia sp.

Zynger et al. (2007) described that eosinophil and monocyte counts in dogs infected by Babesia sp. remained within the reference values, without assigning values. Furlanello et al. (2005) did not find monocytosis in infected animals. However, presently, monocytosis and eosinophilia were present in $11.1 \%$ and $22 \%$ of the infected animals, respectively.

Lymphopenia was evident in 78\% (7/9) of the samples. This differs markedly from the $7.2 \%$ (18/248) rate reported by Zynger et al. (2007). The difference can be related to the stage of infection caused by this protozoan (Bourdoiseau, 2006) or associated infections (Thrall, 2007).

Thrombocytopenia was the most frequently observed alteration, accounting for 89\% (8/9) of piroplasm-positive animals. This result agrees with the rate of 99.5\% (247/248) reported by Zynger et al. (2007). As reported in a study conducted by Furlanello et al. (2005), all animals presented moderate to severe thrombocytopenia. The isolated occurrence of thrombocytopenia, without changes in the other parameters of the hemogram, has been described in many cases of babesiosis and can be related to the immune system, splenic sequestration, or peripheral platelet consumption due to hemolytic alteration or vascular injury (Wilkerson et al., 2001).

Regenerative immune-mediated hemolytic anemia, leukocytosis, leukopenia, and thrombocytopenia are found in babesiosis, as described by Solano-Gallego et al. (2008) and Carli et al. (2009). According to Weiss \& Wardrop (2010), hematological manifestations in cases of babesiosis caused by B. canis sensu lato include hemolytic anemia and thromocytopenia.

The quantitative results that have been obtained are generally contradictory, ranging from the absence of anemia to severe anemia, neutropenia, or leukocytosis, among others. These contradictory results are due to the heterogeneity of the studied populations and the variable time of sampling. However, the first changes are usually thrombocytopenia, eosinopenia, and lymphopenia (Bourdoiseau, 2006).

In a study by Guimarães et al. (2004) that involved 500 dogs in Rio de Janeiro, the most common alterations caused by Babesia sp. infection were hypochromic normocytic anemia, anisocytosis and polychromasia, neutrophilic leukocytosis, monocytosis, lymphopenia, and thrombocytopenia. Similar data were found in the current study, where it was possible to detect the presence of normochromic normocytic anemia, anisocytosis and polychromasia, leukopenia, lymphopenia, and thrombocytopenia in most animals.

\section{Conclusion}

The results suggest that $B$. vogeli is the parasitic piroplasm affecting dogs in the Baixada Fluminense region of Rio de Janeiro. The piroplasm mainly causes anemia and thrombocytopenia in these animals.

\section{References}

Abdullahi, S. U., Mohammed, A. A., Trimnell, A. R., Sannusi, A., \& Alafiatayo, R. (1990). Clinical and haematological findings in 70 naturally occuring cases of canine babesiosis. The Journal of Small Animal Practice, 31(3), 145147. http://dx.doi.org/10.1111/j.1748-5827.1990.tb00750.x.

Araújo, A. C., Silveira, J. A. G., Azevedo, S. S., Nieri-Bastos, F. A., Ribeiro, M. F. B., Labruna, M. B., \& Horta, M. C. (2015). Babesia canis vogeli infection in dogs and ticks in the semiarid region of Pernambuco, Brazil. Pesquisa Veterinária Brasileira, 35(5), 456-461. http://dx.doi.org/10.1590/S0100-736X2015000500012. 
Ayoob, A. L., Hackner, S. G., \& Prittie, J. (2010). Clinical management of canine babesiosis. Journal of Veterinary Emergency and Critical Care(San Antonio, Tex.: 2001),20(1), 77-89. http://dx.doi.org/10.1111/j.1476-4431.2009.00489.x. PMid:20230437.

Bastos, C. V., Moreira, S. M., \& Passos, L. M. F. (2004). Retrospective study (1998-2001) on canine babesiosis in Belo Horizonte, Minas Gerais State, Brazil. Annals of the New York Academy of Sciences, 1026(1), 158-160. http:// dx.doi.org/10.1196/annals.1307.023. PMid:15604486.

Beck, R., Vojta, L., Mrljak, V., Marinculic, A., Beck, A., Zivicnjak, T., \& Cacciò, S. M. (2009). Diversity of Babesia and Theileria species in symptomatic and asymptomatic dogs in Croatia. International Journal for Parasitology, 39(7), 843-848. http://dx.doi.org/10.1016/j.ijpara.2008.12.005. PMid:19367832.

Birkenheuer, A. J. (2012). Babesiosis. In C. E. Greene (Ed.), Infectious diseases of the dog and cat (4th ed., pp. 771784). USA:Elsevier.

Birkenheuer, A. J., Neel, J., Ruslander, D., Levy, M. G., \& Breitschwerdt, E. B. (2004). Detection and molecular characterization of a novel large Babesia species in a dog. Veterinary Parasitology, 124(3-4), 151-160. http:// dx.doi.org/10.1016/j.vetpar.2004.07.008. PMid:15381295.

Bourdoiseau, G. (2006). Canine babesiosis in France. Veterinary Parasitology, 138(1-2), 118-125. http://dx.doi. org/10.1016/j.vetpar.2006.01.046. PMid:16507334

Cacciò, S. M., Antunovic, B., Moretti, A., Mangili, V., Marinculic, A., Baric, R. R., Slemenda, S. B., \& Pieniazek, N. J. (2002). Molecular characterization of Babesia canis canis and Babesia canis vogeli from naturally infected European dogs. Veterinary Parasitology, 106(4), 285-292. http://dx.doi.org/10.1016/S0304-4017(02)00112-7. PMid:12079734.

Carli, E., Tasca, S., Trotta, M., Furlanello, T., Caldin, M., \& Solano-Gallego, L. (2009). Detection of erythrocyte binding IgM and IgG by flow cytometry in sick dogs with Babesia canis canis or Babesia canis vogeli infection. Veterinary Parasitology, 162(1-2), 51-57. http://dx.doi.org/10.1016/j.vetpar.2009.02.002. PMid:19269745.

Carret, C., Walas, F., Carcy, B., Grande, N., Précigout, E., Moubri, K., Schetters, T. P., \& Gorenflot, A. (1999). Babesia canis canis, Babesia canis vogeli, Babesia canis rossi: differentiation of the three subspecies by a restriction fragment length polymorphism analysis on amplified small subunit ribosomal RNA genes. The Journal of Eukaryotic Microbiology, 46(3), 298-303. http://dx.doi.org/10.1111/j.1550-7408.1999.tb05128.x. PMid:10377990.

Criado-Fornelio, A., Martinez-Marcos, A., Buling-Saraña, A., \& Barba-Carretero, J. C. (2003). Molecular studies on Babesia, Theileria and Hepatozoon in Southern Europe: Part I. Epizootiological aspects. Veterinary Parasitology, 113(3-4), 189-201. http://dx.doi.org/10.1016/S0304-4017(03)00078-5. PMid:12719133.

Eiras, D. F., Craviotto, M. B., Baneth, G., \& Moré, G. (2014). First report of Rangelia vitalii infection (canine rangeliosis) in Argentina. Parasitology International, 63(5), 729-734. http://dx.doi.org/10.1016/j.parint.2014.06.003. PMid:24970768.

Felsenstein, J. PHYLIP (Phylogeny Inference Package) version 3.6. Distributed by the author. Department of Genome Sciences, University of Washington, Seattle, 2005.

Furlanello, T., Fiorio, F., Caldin, M., Lubas, G., \& Solano-Gallego, L. (2005). Clinicalpathological findings in naturally occurring cases of babesiosis caused by large form Babesia from dogs of northeastern Italy. Veterinary Parasitology, 134(1-2), 77-85. http://dx.doi.org/10.1016/j.vetpar.2005.07.016. PMid:16112810.

García, A. T. C. (2006). Piroplasma infection in dogs in northern Spain. Veterinary Parasitology, 138(1-2), 97-102. http://dx.doi.org/10.1016/j.vetpar.2006.01.043. PMid:16513282.

Guimarães, J. C., Albernaz, A. P., Machado, J. A., Junior, O. A. M., \& Garcia, L. N. N. (2004). Aspectos clinicolaboratoriais da babesiose canina na cidade de Campos dos Goytacazes, RJ. Revista Brasileira de Parasitologia Veterinária, 13, 229.

Irwin, P. J. (2009). Canine babesiosis: from molecular taxonomy to control. Parasites \& Vectors, 2(Suppl 1), S4. http://dx.doi.org/10.1186/1756-3305-2-S1-S4.

Kjemtrup, A. M., \& Conrad, P. A. (2006). A review of the small canine piroplasms from California: Babesia conradae in the literature. Veterinary Parasitology, 138(1-2), 112-117. http://dx.doi.org/10.1016/j.vetpar.2006.01.045. PMid:16522352.

Kjemtrup, A. M., Wainwright, K., Miller, M., Penzhorn, B. L., \& Carreno, R. A. (2006). Babesia conradae, sp. nov., a small canine Babesia identified in California. Veterinary Parasitology, 138(1-2), 103-111. http://dx.doi.org/10.1016/j. vetpar.2006.01.044. PMid:16524663.

Lack, J. B., Reichard, M. V., \& Van Den Bussche, R. A. (2012). Phylogeny and evolution of the Piroplasmida as inferred from 18S rRNA sequences. Internaciol Journal for Parasitology, 42(4), 353-363. http://dx.doi.org/10.1016/j. ijpara.2012.02.005. PMid:22429769.

Larkin, M. A., Blackshields, G., Brown, N. P., Chenna, R., McGettigan, P. A., McWilliam, H., Valentin, F., Wallace, I. M., Wilm, A., Lopez, R., Thompson, J. D., Gibson, T. J., \& Higgins, D. G. (2007). Clustal W and Clustal X version 2.2. Bioinformatics (Oxford, England), 23(21), 2947-2948. http://dx.doi.org/10.1093/bioinformatics/btm404. PMid:17846036.

Lehtinen, L. E., Birkenheuer, A. J., Droleskey, R. E., \& Holman, P. J. (2008). In vitro cultivation of a newly recognized Babesia sp. in dogs in North Carolina. Veterinary Parasitology, 151(2-4), 150-157. http://dx.doi.org/10.1016/j. vetpar.2007.10.022. PMid:18083310. 
Lemos, T. D., Cerqueira, A. M. F., Toma, H. K., Silva, A. V., Corrêa, R. G. B., Paludo, G. R., Massard, C. L., \& Almosny, N. R. P. (2012). Detection and molecular characterization of piroplasms species from naturally infected dogs in southeast Brazil. Revista Brasileira de Parasitologia Veterinária, 21(2), 137-142. http://dx.doi.org/10.1590/ S1984-29612012000200012. PMid:22832754.

Lobetti, R. G. (2003). Hematological changes in TBDs. In Proceedings of the 21st American College of Veterinary Internal Medicine Forum (pp. 554-556). Charlotte, NC: American College of Veterinary Internal Medicine.

Loretti, A. P., \& Barros, S. S. (2005). Hemorrhagic disease in dogs infected with an unclassified intraendothelial piroplasm in southern Brazil. Veterinary Parasitology, 134(3-4), 193-213. http://dx.doi.org/10.1016/j.vetpar.2005.07.011. PMid:16153781.

Matjila, P. T., Leisewitz, A. L., Oosthuizen, M. C., Jongejan, F., \& Penzhorn, B. L. (2008). Detection of a Theileria species in dogs in South Africa. Veterinary Parasitology, 157(1-2), 34-40. http://dx.doi.org/10.1016/j.vetpar.2008.06.025. PMid:18687528.

Miranda, F. J. B., Albemaz, A. P., Melo Junior, A. O., \& Machado, J. Á. (2008). Frequência de cães infectados por Babesia spp. em Campos dos Goytacazes, RJ. Ciência Animal Brasileira, 9, 238-241.

Miró, G., Checa, R., Paparini, A., Ortega, N., González-Fraga, J. L., Gofton, A., Bartolomé, A., Montoya, A., Gálvez, R., Mayo, P. P., \& Irwin, P. (2015). Theileria annae (syn. Babesia microti-like) infection in dogs in NW Spain detected using direct and indirect diagnostic techniques: clinical report of 75 cases. Parasites \& Vectors, 8(1) 217. http://dx.doi.org/10.1186/s13071-015-0825-2. PMid:25890106.

O'Dwyer, L. H., Massard, C. L., \& Souza, J. C. P. (2001). Hepatozoon canis infection associated with dog ticks of rural areas of Rio de Janeiro State, Brazil. Veterinary Parasitology, 94(3), 143-150. http://dx.doi.org/10.1016/ S0304-4017(00)00378-2. PMid:11113545.

Otto, T. D., Vasconcellos, E. A., Gomes, L. H. F., Moreira, A. S., Degrave, W. M., Mendonça-Lima, L., \& Alves-Ferreira, M. (2008). ChromaPipe: a pipeline for analysis, quality control and managment for a DNA sequencing facility. Genetics and Molecular Research, 7(3), 861-871. http://dx.doi.org/10.4238/vol7-3X-Meeting04. PMid:18949705.

Pantchev, N., Pluta, S., Huisinga, E., Nather, S., Scheufelen, M., Vrhovec, M. G., Schweinitz, A., Hampel, H., \& Straubinger, R. K. (2015). Tick-borne diseases (Borreliosis, Anaplasmosis, Babesiosis) in German and Austrian Dogs: Status quo and Review of Distribution, Transmission, Clinical Findings, Diagnostics and Prophylaxis. Parasitology Research, 114(Suppl 1), S19-S54. http://dx.doi.org/10.1007/s00436-015-4513-0. PMid:26152408.

Passos, L. M. F., Geiger, S. M., Ribeiro, M. F. B., Pfister, K., \& Zahler-Rinder, M. (2005). First molecular detection of Babesia vogeli in dogs from Brazil. Veterinary Parasitology, 127(1), 81-85. http://dx.doi.org/10.1016/j. vetpar.2004.07.028. PMid:15619377.

Sá, A. G., Cerqueira, A. M. F., O'Dwyer, L. H., Macieira, D. B., Abreu, F. S., Ferreira, R. F., Pereira, A. M., Velho, P. B., \& Almosny, N. R. P. (2006). Detection and molecular characterization of Babesia canis vogeli from naturally infected Brazilian dogs. International Journal of Applied Research in Veterinary Medicine, 4, 163-168.

Schnittger, L., Rodriguez, A. E., Florin-Christensen, M., \& Morrison, D. A. (2012). Babesia: A world emerging. Infection, Genetics and Evolution, 12(8), 1788-1809. http://dx.doi.org/10.1016/j.meegid.2012.07.004. PMid:22871652.

Silva, A. S., França, R. T., Costa, M. M., Paim, C. B., Paim, F. C., Dornelles, G. L., Soares, J. F., Labruna, M. B., Mazzanti, C. M., Monteiro, S. G., \& Lopes, S. T. A. (2011). Experimental infection with Rangelia vitalii in dogs: acute phase, parasitemia, biological cycle, clinical-pathological aspects and treatment. Experimental Parasitology, 128(4), 347-352. http://dx.doi.org/10.1016/j.exppara.2011.04.010. PMid:21570966.

Soares, A. O., Souza, A. D., Feliciano, E. A., Rodrigues, A. F. S. F., D’Agosto, M., \& Daemon, E. (2006). Avaliação ectoparasitológica e hemoparasitológica em cães criados em apartamentos e casas com quintal na cidade de Juiz de Fora, MG. Revista Brasileira de Parasitologia Veterinária, 15(1), 13-16. PMid:16646996.

Soares, J. F., Carvalho, L., Maya, L., Dutra, F., Venzal, J. M., \& Labruna, M. B. (2015). Molecular detection of Rangelia vitalii in domestic dogs from Uruguay. Veterinary Parasitology, 210(1-2), 98-101. http://dx.doi.org/10.1016/j. vetpar.2015.03.013. PMid:25843009.

Soares, J. F., Girotto, A., Brandão, P. E., Da Silva, A. S., França, R. T., Lopes, S. T. A., \& Labruna, M. B. (2011). Detection and molecular characterization of a canine piroplasm from Brazil. Veterinary Parasitology, 180(3-4), 203-208. http://dx.doi.org/10.1016/j.vetpar.2011.03.024. PMid:21489694.

Solano-Gallego, L., Trotta, M., Carli, E., Carcy, B., Caldin, M., \& Furlanello, T. (2008). Babesia canis canis and Babesia canis vogeli clinicopathological findings and DNA detection by means of PCR-RFLP in blood from Italian dogs suspected of tick-borne disease. Veterinary Parasitology, 157(3-4), 211-221. http://dx.doi.org/10.1016/j. vetpar.2008.07.024. PMid:18789581.

Taboada, J., \& Lobetti, R. (2006). Babesiosis. In C. E. Greene (Ed.), Infectious diseases of the dog and cat (p. 722). Philadelphia: Saunders Elsevier.

Thrall, M. A. (2007). Hematologia das espécies domésticas comuns. In M. A. Thrall. Hematologia e bioquímica clínica veterinária (pp. 63-89). São Paulo: Roca.

Trapp, S. M., Messick, J. B., Vidotto, O., Jojima, F. S., \& Morais, H. S. A. (2006). Babesia gibsoni genotype Asia in dogs from Brazil. Veterinary Parasitology, 141(1-2), 177-180. http://dx.doi.org/10.1016/j.vetpar.2006.04.036. PMid:16765518.

Uilenberg, G. (2006). Babesia: a historical overview. Veterinary Parasitology, 138(1-2), 3-10. http://dx.doi.org/10.1016/j. vetpar.2006.01.035. PMid:16513280. 
Ungar de Sá, M. F. M., Ungar de Sá, J. E., Bittencourt, D. V. V., Bispo, A. C., Régis, A. M. M., Souza Filho, N. D. J. \& Franke, C. R. Estudo retrospectivo (1991-2005) dos casos de babesiose canina na cidade de Salvador e Região Metropolitana, Bahia. Revista Brasileira de Saúde e Produção Animal, 8:178-183, 2007.

Weiss, D. J., \& Wardrop, K. J. (2010). Schalm's veterinary hematology (6th ed., 1232 p.). Ames: Blackwell Publishing Ltd.

Wilkerson, M. J., Shuman, W., Swist, S., Harkin, K., Meinkoth, J., \& Kocan, A. A. (2001). Platelet size, platelet surfaceassociated IgG, and reticulated platelets in dogs with immune-mediated thrombocytopenia. Veterinary Clinical Pathology, 30(3), 141-149. http://dx.doi.org/10.1111/j.1939-165X.2001.tb00423.x. PMid:12024314.

Yeagley, T. J., Reichard, M. V., Hempstead, J. E., Allen, K. E., Parsons, L. M., White, M. A., Little, S. E., \& Meinkoth, J. H. (2009). Detection of Babesia gibsoni and the canine small Babesia 'Spanish isolate' in blood samples obtained from dogs confiscated from dogfighting operations. Journal of the American Veterinary Medical Association, 235(5), 535-539. http://dx.doi.org/10.2460/javma.235.5.535. PMid:19719443.

Zahler, M., Rinder, H., Schein, E., \& Gothe, R. (2000a). Detection of a new pathogenic Babesia microti-like species in dogs. Veterinary Parasitology, 89(3), 241-248. http://dx.doi.org/10.1016/S0304-4017(00)00202-8. PMid:10760414.

Zahler, M., Rinder, H., Zweygarth, E., Fukata, T., Maede, Y., Schein, E., \& Gothe, R. (2000b). Babesia gibsoni of dogs from North America and Asia belong to different species. Parasitology, 120(Pt 4), 365-369. http://dx.doi. org/10.1017/S0031182099005557. PMid:10811277.

Zynger, W., Gójska, O., Rapacka, G.; Jaros, D., Wedrychowicz, H. (2007) Hematological changes during the course of canine babesiosis caused by large Babesia in domestic dogs in Warsaw (Poland). Veterinary Parasitology, 145(1),146-151. https://doi.org/10.1016/j.vetpar.2006.11.008. 